\title{
Research on Strong Ground Pressure of Multiple-Seam Caused by Remnant Room Pillars Undermining in Shallow Seams
}

\author{
Dan Yu ${ }^{1,2} \mathbb{D}$, Xiaoyong $Y i^{2, *(\mathbb{D})}$, Zhimeng Liang ${ }^{2}(\mathbb{D})$, Jinfu Lou ${ }^{3}$ and Weibing Zhu ${ }^{1,2, *(\mathbb{D})}$ \\ 1 State Key Laboratory of Coal Resources and Safe Mining, China University of Mining and Technology, \\ Xuzhou 221116, China; ts20020179p21@cumt.edu.cn \\ 2 School of Mines, China University of Mining and Technology, Xuzhou 221116, China; \\ liangmeng1019@163.com \\ 3 China Coal Technology and Engineering Group Co., Ltd., Coal Mining Research Institute, \\ Beijing 100013, China; loujinfu@tdkcsj.com \\ * Correspondence: TS18020059A3TM1@cumt.edu.cn (X.Y.); cumtzwb@cumt.edu.cn (W.Z.)
}

Citation: Yu, D.; Yi, X.; Liang, Z.;

Lou, J.; Zhu, W. Research on Strong Ground Pressure of Multiple-Seam Caused by Remnant Room Pillars Undermining in Shallow Seams. Energies 2021, 14, 5221. https:// doi.org/10.3390/en14175221

Academic Editor: Adam Smoliński

Received: 4 August 2021

Accepted: 21 August 2021

Published: 24 August 2021

Publisher's Note: MDPI stays neutral with regard to jurisdictional claims in published maps and institutional affiliations.

Copyright: (c) 2021 by the authors. Licensee MDPI, Basel, Switzerland. This article is an open access article distributed under the terms and conditions of the Creative Commons Attribution (CC BY) license (https:// creativecommons.org/licenses/by/ $4.0 /)$.

\begin{abstract}
Numerous room-and-pillar mining goaf are apparent in western China due to increasing small coal mining activities, which causes the collapse of the overlying coal pillars and the occurrence of strong ground pressure on the longwall face and surface subsidence. In this study, Yuanbao Bay Coal Mine, Shuozhou, Shanxi, was selected to study the collapse of the overlying coal pillars on the longwall face and reveal the mechanism of the pillar collapse and the disaster-causing mechanism caused by strong ground pressure. Results show that the dynamic collapse process of coal pillars is relatively complicated. First, the coal pillars on both sides of the goaf are destroyed and destabilized, followed by the adjacent coal pillars, which eventually cause a large-scale collapse of the coal pillars. This results in a large-scale cut-off movement of the overlying strata, and the large impact load that acts on the longwall face causes an unmovable longwall face support. Moreover, the roof weighting is severe when strong ground pressure occurs on the longwall face, causing local support jammed accidents. Furthermore, the data of each measurement point of the strata movement inside the ground borehole significantly increases, and the position of the borescope peeping error holes in the ground drill hole rise steeply. The range of movement of the overlying strata increases instantaneously, and the entire strata begin to move. Research on the mechanism of strong ground pressure can effectively prevent mine safety accidents and avoid huge economic losses.
\end{abstract}

Keywords: undermining; room pillar; multiple-seam; dynamic load pressure; pillar collapse; strata movement

\section{Introduction}

Coal, which is one of the main energy sources of China, plays a significant role in China's energy consumption structure. Particularly, western China became the concentrated place of numerous and increasing mining activities in the past decades. Most mining operations in these regions occur in shallow-buried and close-distance coal seams [1] Existing and upper coal seams with simple geological conditions have been mined due to the intensive mining activities in recent years, and the mining process of the close-distance lower coal seam has been inevitably affected in secondary mining. This multiple-seam mining [2-5] causes an increase in the overburden movement range and surface damage. Moreover, the abnormal stress field and movement of the overlying strata in the stope causes the appearance of abnormal ground pressure, resulting in the increasing attention that close-distance coal seam mining has received in recent years [6,7].

The main problem in the Yuanbao Bay Mine in Shuozhou, Shanxi, is ensuring the stability of the overlying coal pillars affected by undermining [2,3,8-12]. Several theoretical and numerical studies have been conducted to address this problem and evaluate the stability of coal pillars, including the modeling and calculation of coal pillar bearings [13-15], 
determination of the mechanical characteristics of coal pillars under long-term bearing action [16-18], investigation of the function evaluation method of the coal pillar stability [19], and the identification of the main factors affecting the stability of coal pillars [20,21].

The overlying coal seam goaf is affected by lower seam undermining if it is a roomand-pillar mined-out area. Moreover, the coal pillar collapse mechanism, the influence of this collapse on the working face of the lower coal seam, and the surface subsidence [22] when the overlying coal pillar loses stability have been extensively studied by several experts and scholars.

Therefore, the large-area support crushing is crucial and necessary due to the movement and instability of the overburden structure. Some scholars systematically analyzed the large-area support crushing event of stope in China and found that the articulated rock block structure formed by the key strata of the overburden lacks stability [23] and causes the large-area support crushing event in a stope. Therefore, the working resistance [24] of the working face support should be at a high level to prevent support crushing. Meanwhile, Wang et al. [25] investigated the principles behind the destruction of loose confined aquifers in mining and revealed the important role of the unconsolidated confined aquifer (UCA) in the process of load transfer due to its liquidity and timely replenishment [26]. On the other hand, Huang et al. [27] focused on the number of key strata in shallow-buried and closedistance coal seams and determined that different overlying strata structures were formed after one or two layers were broken. Additionally, the structure formed by one broken layer was carried together in the form of hinged arches and arch shells, while the structure of two broken layers was formed in a variety of combinations of steps and masonry, and the composite overburden structure jointly bears the load of the overburden. Zhu et al. [28] studied the roof damage in room-and-pillar mined-out areas caused by longwall mining in the lower coal seam and observed that different width-to-height ratios of coal pillars lead to different modes of collapse failure [29] and provided reference values for the development trend of the cracks after collapse of different width-to-height ratios of coal pillars during mining underneath the goaf. Wang et al. [30,31] have done great research on automatically formed roadway (AFR) and found that the new mining method satisfies the surrounding rock control requirement, which improves the safety and economic impact of coal mining. Feng et al. [32], using the key stratum theory, put forward the concepts of key stratum breaking distance and advancing mining coal pillars to address the problem of coal seam mining above the knife-pillar goaf and formed the knife-pillar goaf overmining [33-35] feasibility judgment theory and method. Wang et al. [36] comprehensively considered the factors influencing the stability of the interburden and adopted the safety factor method to evaluate the stability of the interburden in order to ensure the safe mining of a coal seam that overlies the knife-pillar goaf area. Dychkovskyi R. et al. [37] conducted research into stress-strain state of the rock mass condition in the process of the operation of double-unit longwalls in order to substantiate changes in stress-strain state of rock mass in the process of long-pillar mining with the help of double-unit longwalls while evaluating stress of a mine field in terms of Lvivvuhillia SE mine.

However, most of the existing research is only aimed at the collapse of coal pillar groups under static load. There is limited research on the stability of coal pillars and the dynamic collapse process of coal pillar groups under the influence of mining. Additionally, there is only one layer of the room-and-pillar mined-out region in overburden, which cannot show the dynamic collapse process. This limits the investigation into the combination collapse of the coal pillar and the roof during the dynamic collapse process. Meanwhile, new measurement method is applied to the strata movement, optical fiber is employed during strata movement monitoring to detect the displacement through strain [38-40]. However, the cumulative strain calculation displacement causes a certain error. Based on the aforementioned limitations of the previous studies, this study considers the Yuanbao Bay 6107 longwall face $[2,3,41]$ as the study location in order to investigate the stability of the coal pillar in undermining conditions using the adopted experimental method. By adopting the three key strata shift measurement point layout, this experiment captured 
the violent settlement caused by strong ground pressure, then studied the mechanism of the dynamic collapse of the coal pillar group through physical simulation, and finally, deeply analyzed the mechanism of the disaster through a simplified model. This research achieved the goal of monitoring the movement characteristics [42] of the overlying strata and studying the disaster-causing mechanism of strong ground pressure as well as monitoring the movement characteristics of the overlying strata and studying the disaster mechanism caused by strong ground pressure. Moreover, this study represents an important contribution to the prevention and control of support crushing disasters by putting forward effective measures and countermeasures to guarantee the safety of mine personnel, equipment, and facilities by predicting the initial location of an occurrence of strong ground pressure and carrying out effective prevention and control through methods like hydraulic fracturing to solve the vulnerabilities in advance.

\section{Basic Conditions of Longwall Face}

There are four key strata in the overburden of the 6107 longwall face, all of which are medium sandstone, based on the borehole columnar section 2101. From bottom to top, the lowest region has a burial depth of $148.9 \mathrm{~m}$ and a thickness of $7.75 \mathrm{~m}$, which exist in the inferior key stratum between the No. 6 and No. 4 coal seams. The next layer has a burial depth of $126.3 \mathrm{~m}$ and an inferior key stratum thickness of $8.8 \mathrm{~m}$. Then, the succeeding layer has a burial depth of $76.7 \mathrm{~m}$, and the thickness of the inferior key stratum is $5.5 \mathrm{~m}$. Finally, the main key stratum has a burial depth of $49.5 \mathrm{~m}$ and a thickness of $10.5 \mathrm{~m}$.

The mining method adopted in this study is one-time full-height longwall retreating mining with the 6107 longwall face having an advancing length of $500 \mathrm{~m}$, a width of $240 \mathrm{~m}$, an average coal seam thickness of $3.5 \mathrm{~m}$, an inclination angle of $4^{\circ}$ to $8^{\circ}$ (with an average of $6^{\circ}$ ), and a coal seam burial depth of approximately $150 \mathrm{~m}$. The No. 6 coal seam is overlaid by the room-and-pillar mining goaf formed by small coal kilns before integrating No. 3 and No. 4 coal seams. There is still a certain bearing capacity based on the preliminary exploration. Combining the actual survey results on the site, the coal pillar widths of No. 3 and No. 4 coal seams are approximately $5-7 \mathrm{~m}$, and the goaf of them are about $4-6 \mathrm{~m}$.

The main problem with mining in the 6107 longwall face of Yuanbao Bay Mine is the threat of collapse of the coal pillars in the room-and-pillar mined-out area in the overlying 3 and 4 coal goaf. If the overlying goaf is affected by the undermining of the No. 6 coal seam longwall faces, it will cause a large-scale collapse that will result in the overall breaking movement of the overburden, inducing the occurrence of dynamic loading ground pressure disasters on the longwall face.

\section{Characteristics of Strong Ground Pressure}

\subsection{Location and Situation of Strong Ground Pressure}

A strong ground pressure event occurred on August 12. The head and tail positions of the 6107 longwall face were advanced to 318 and $325 \mathrm{~m}$ (with an average distance of $322 \mathrm{~m}$ ), respectively. The pressure on support Nos. 16 to 135 exceeded $40 \mathrm{MPa}$, and all safety valves were opened. Among them, support Nos. 110 to 135 and Nos. 80 to 110 had a stroke of support movable column of 60 and $40 \mathrm{~cm}$, respectively. In addition, support Nos. 16 to 80 had no stroke. The supports were crushed, and the advance of the longwall face was stopped for several days. Figure 1 shows the range of the longwall face support crushing and the position of the newly developed fractures [43]. 


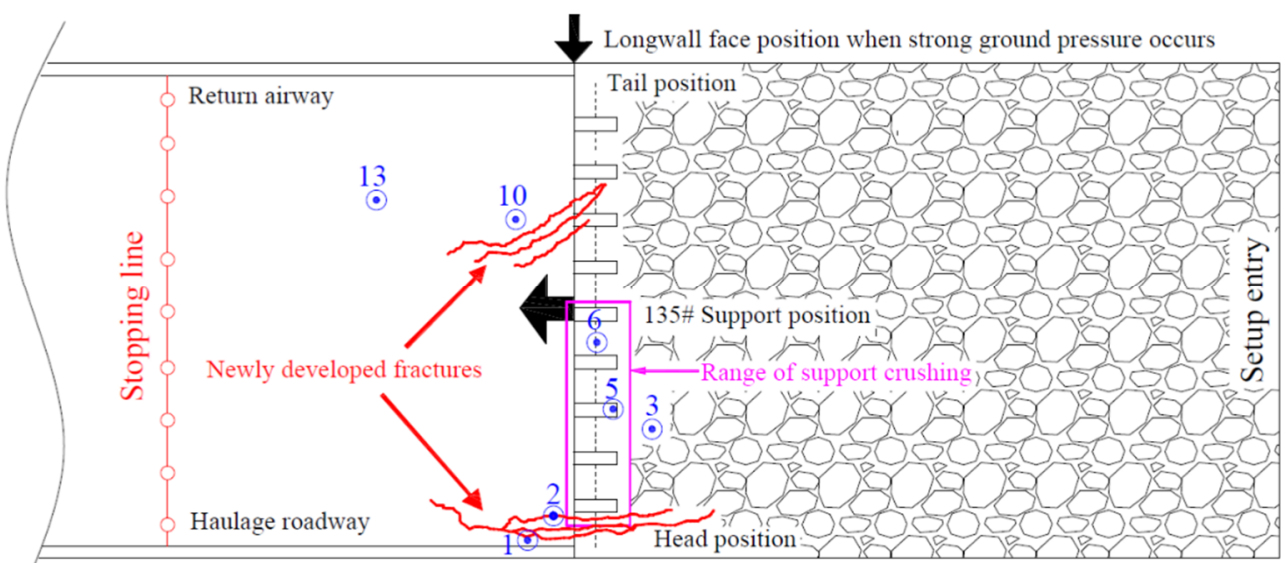

Figure 1. Plan view of the position of the newly developed fractures and the range of longwall face support crushing.

On the day of the occurrence of strong ground pressure, a detailed survey of the development of the surface fractures was carried out. According to the survey results, it was found that two groups of newly developed surface fractures appeared at the position, $50 \mathrm{~m}$ in front of the longwall face, and each group of fractures consisted of 3-4 stepped fractures, as shown in Figure 1. The first group of fractures was approximately located near holes No. 1 and No. 2, and the second group was approximately located near hole No. 10. The direction of the fractures was roughly along the longwall face advancing direction. The surface fractures near hole No. 2 developed as shown in Figure 2. The maximum width of these surface fractures was $1.0 \mathrm{~m}$, and the maximum displacement of the steps was $0.8 \mathrm{~m}$.

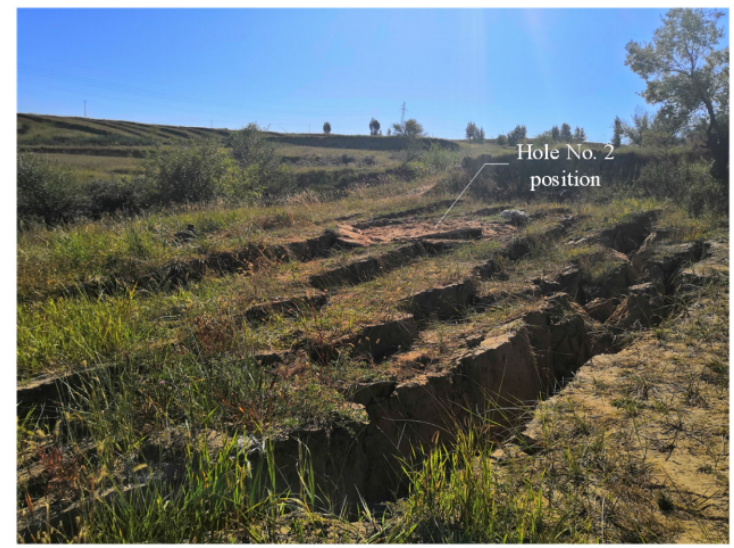

Figure 2. Surface fracture development near hole No. 2.

\subsection{Characteristics of Unstable Overburden Movement under Strong Ground Pressure}

To further understand the characteristics of the overburden movement, it was decided to arrange multiple strata movement measuring points at the key stratum position as required. A strong ground pressure phenomenon was observed during the monitoring, and the strata movement characteristics when strong ground pressure occurred were captured. Holes No. 6 and 10 were chosen as the internal strata displacement installation holes based on the results of the borehole columnar section, key stratum identification, and the investigation results of the longwall face drill hole. Specifically, the position of hole No. 6 was in the center of the range of the newly developed fractures and used to illustrate the overburden movement process, the No. 6 drill hole installation plan, as is shown in Figure 3a, and the remaining holes (i.e., 1, 2, 3, 5, and 13) of grouting used for the borescope peeping. 


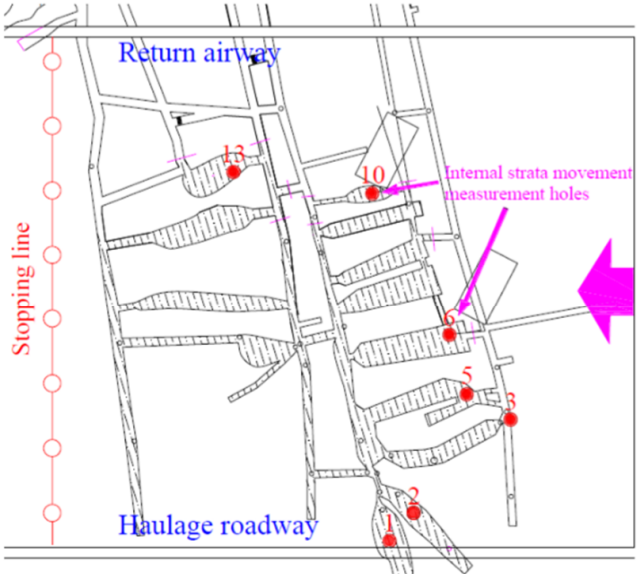

(a)

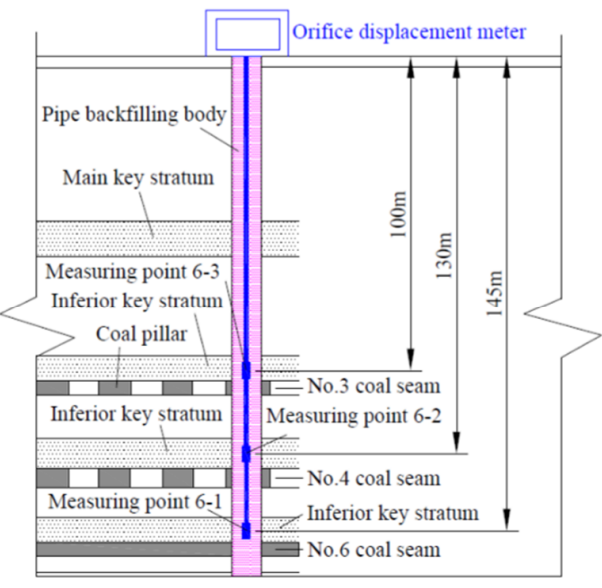

(b)

Figure 3. Internal strata movement installation plan of the longwall face. (a) Installation plan of the internal strata movement measurement and observation holes; (b) Diagram of the internal strata movement measurement hole No. 6 installation.

A schematic diagram of the internal strata movement measurement hole No. 6 installation is shown in Figure $3 b$, where each measuring point represents the movement state of each key stratum and its controlled strata. The alternative relationship between each measuring point sinking amount and the distance between the 6107 longwall face and hole No. 6 is shown in Figure 4.

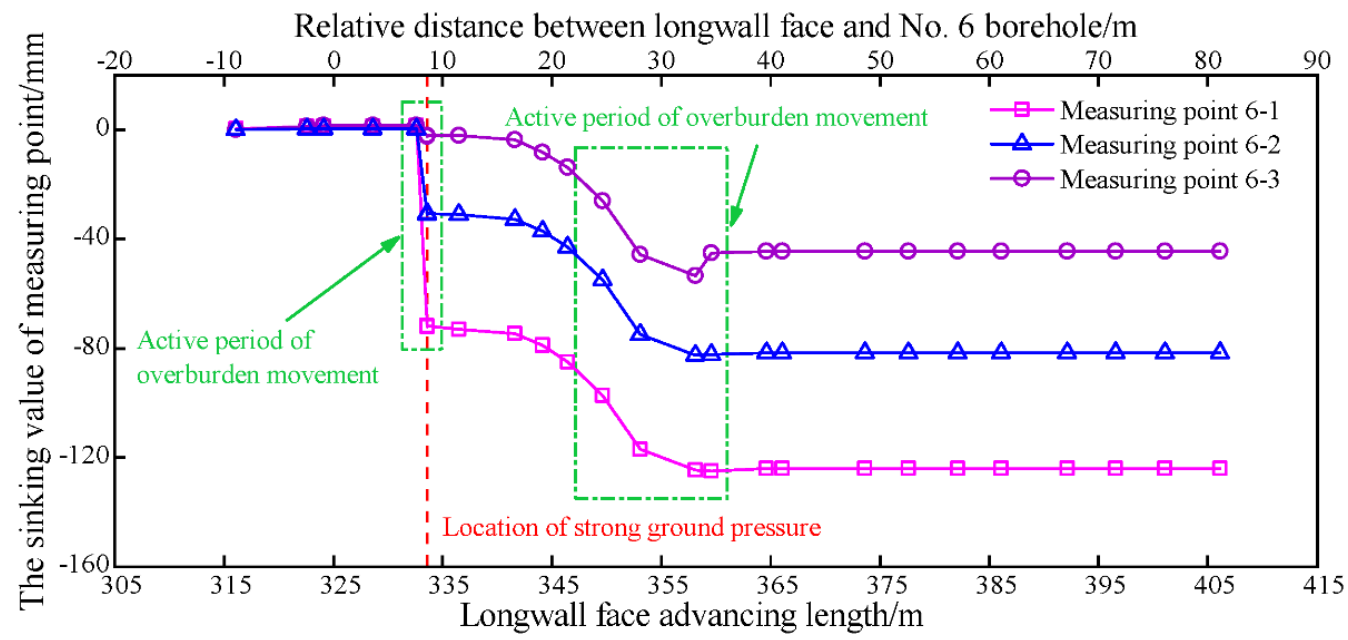

Figure 4. Relationship between each measuring point sinking amount and the distance between the 6107 longwall face and hole No. 6.

Figure 4 shows a large sinking amount of measuring points 6-1 and 6-2 with sinking increments of 70 and $30 \mathrm{~mm}$, fast change process, and short and rapid time when the longwall face is pushed through the hole for about $8 \mathrm{~m}$, indicating that the first step subsidence occurred in the strata corresponding to the two measuring points that are in the active period, which is short, of the overburden movement. All measuring points change slowly for a long period when the longwall face is pushed through the hole at approximately $28 \mathrm{~m}$. The total increments of its subsidence were 120,80 , and $40 \mathrm{~mm}$, with the relative increments of 50,50, and $40 \mathrm{~mm}$, respectively. This indicates that the strata corresponding to the three measurement points had secondary step subsidence with a similar amount of subsidence, an active overburden movement, and a relatively longer active period. After these two active periods, the sinking value did not change significantly. 
The ground pressure on the longwall face was extremely intense during the large-scale movement of the overburden. In addition, the time and location of the sinking experienced by hole No. 6 had a one-to-one correspondence with the time and location of the strong ground pressure on the longwall face, indicating that the active period of the overburden movement and the occurrence of the strong ground pressure on the longwall face are inseparable.

\subsection{Results of the Drill Hole Borescope Peeping}

Borehole No. 1 is within the range of newly developed fractures, reflecting the detailed process of the overlying strata movement, as shown in Figure 5.

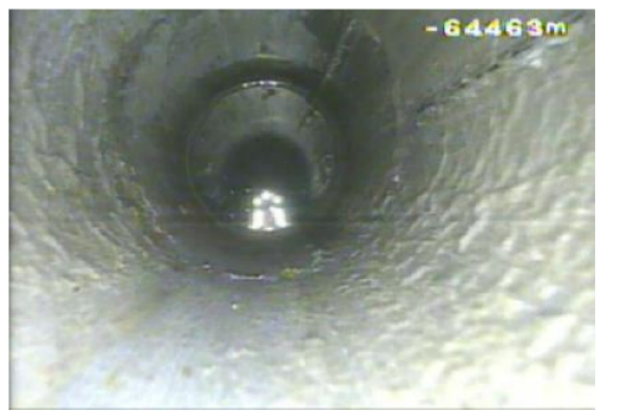

(a)

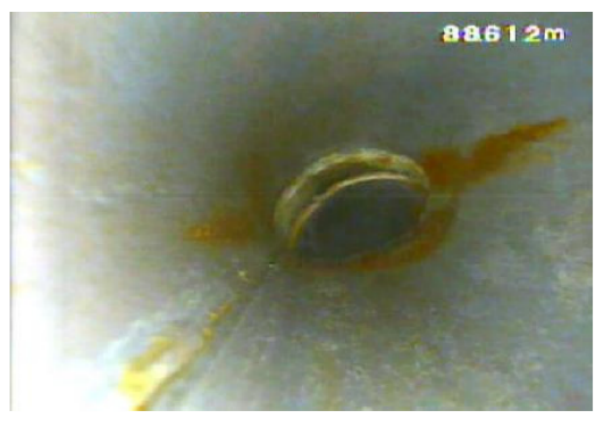

(c)

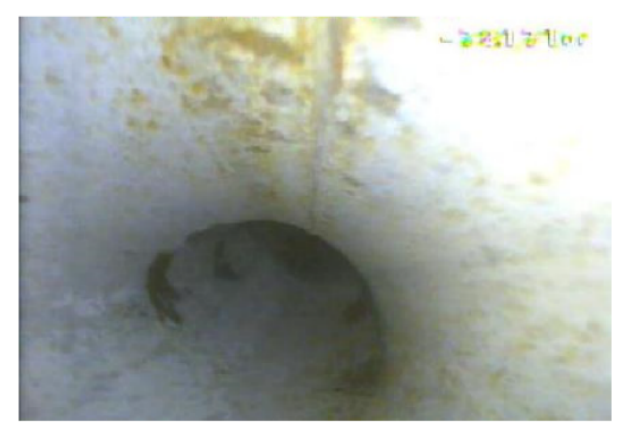

(e)

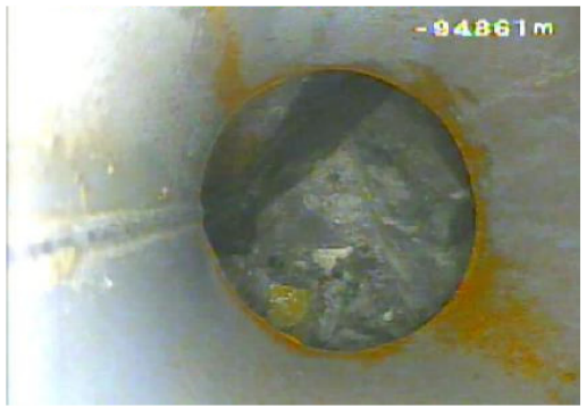

(b)

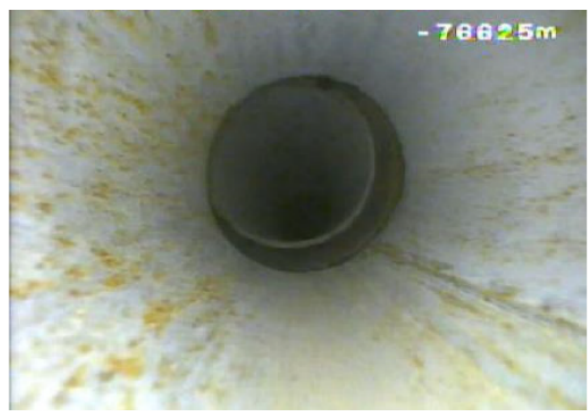

(d)

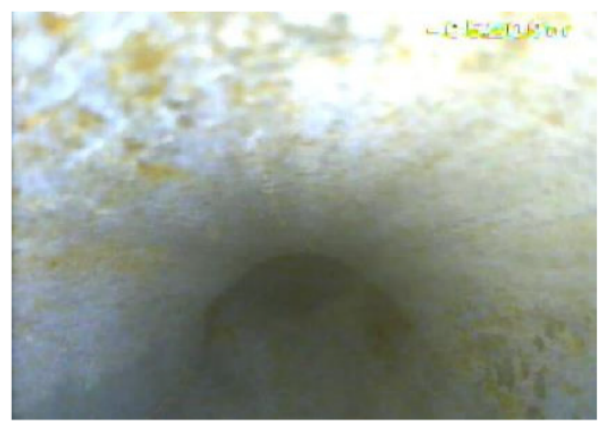

(f)

Figure 5. Observation results of borehole No. 1. (a) Water accumulation location at $-64.46 \mathrm{~m}$; Error hole position at (b) $-94.86 \mathrm{~m},(\mathbf{c})-88.61 \mathrm{~m},(\mathbf{d})-78.82 \mathrm{~m},(\mathbf{e})-73.17 \mathrm{~m}$, and (f) $-35.20 \mathrm{~m}$.

The observations started when borehole No. 1 was $53 \mathrm{~m}$ away from the longwall face. Results from the observations show that the probe was lowered to $-64.46 \mathrm{~m}$, wherein water accumulated in the hole, and cracks under the hole did not develop. Therefore, the probe was stopped, as shown in Figure 5a. Additionally, the probe was lowered to approximately $-94.86 \mathrm{~m}$ when the longwall face was $20 \mathrm{~m}$ from the hole. Error holes in the hole were found, and the distance between them was relatively large, as shown in 
Figure $5 \mathrm{~b}$. Moreover, the position of the staggered hole in the hole remained unchanged at $-94.86 \mathrm{~m}$ when the longwall face was 17 to $0 \mathrm{~m}$. We found error holes when the probe was lowered to a position of approximately $-88.61 \mathrm{~m}$, and the longwall face was pushed through the hole at $5 \mathrm{~m}$. The distance of the error holes was not large, but the probe was not able to pass, and the descending was forced to stop, as shown in Figure 5c. During the 6 to $27 \mathrm{~m}$ period when the longwall face pushed through the hole, the position of the error hole did not change. When the longwall face was pushed through $33 \mathrm{~m}$, it was found that when the probe was lowered to about $-78.82 \mathrm{~m}$, the drill hole was slightly wrong, the casing fell off, the probe could not pass, and the detection ended, as shown in Figure $5 \mathrm{~d}$. The position of the error hole remained unchanged from 39 to $43 \mathrm{~m}$ when the longwall face was pushed through the borehole. The probe went down to approximately $-73.17 \mathrm{~m}$, and the error hole occurred when the longwall face was pushed through the borehole for more than $48 \mathrm{~m}$. The error hole was not completely closed, but the probe could not pass through, so it stopped descending, as shown in Figure 5e. In the 53-58 m period, the position of the error hole remained unchanged when the longwall face was pushed through the borehole. On the other hand, the probe was lowered to $-35.20 \mathrm{~m}$, and the error hole occurred when the longwall face was pushed through the hole at $64 \mathrm{~m}$, as shown in Figure $5 \mathrm{f}$. It was of little use to continue the detection because the position of the error hole was already above the main key stratum. Thus, the borescope observation was complete.

According to the above observation results, the relationship of the depth and the relative distance between the longwall face and hole No. 1 and the position of the staggered hole can be obtained, as shown in Figure 6. The first misalignment of the hole coincides with the location of the strong ground pressure, indicating that the large movement of the overlying strata below the inferior key stratum is the main cause of the strong ground pressure. In the subsequent mining engineering of the longwall face, the position of the error hole has a small step rise, and finally, the position of the error hole near the loose layer no longer changes. The observation results indicate that the entire overburden movement has a stepwise upward trend.

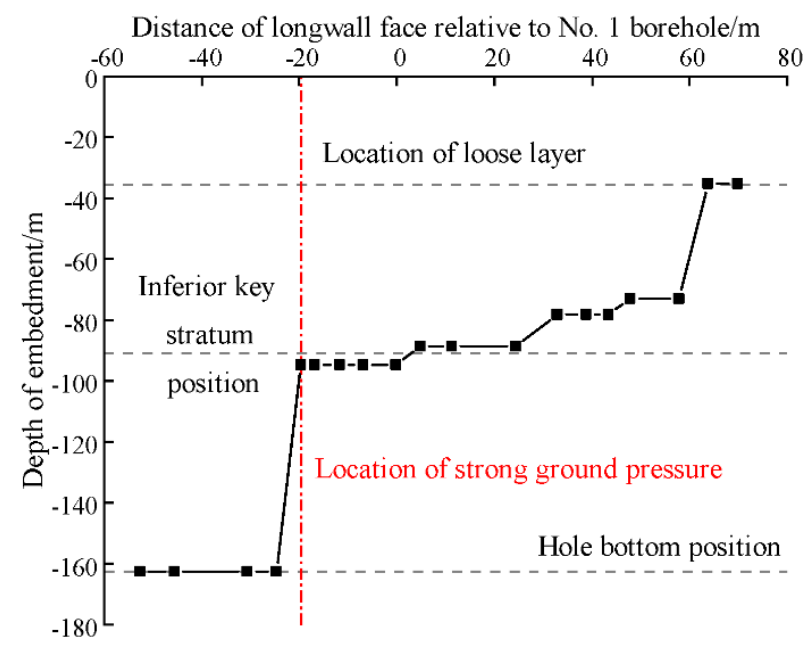

Figure 6. Relationship between the depth of misaligned holes in No. 1 borehole and the distance of longwall face relative to No. 1 borehole.

\section{Dynamic Collapse Process of Room Pillars and the Disaster Mechanism caused by Strong Ground Pressure}

\subsection{Scheme Design of the Similar Simulation Model}

The occurrence of the strong ground pressure disaster on the 6107 longwall face was caused by the overall movement of the overburden. Therefore, we employed a similar simulation [44] to study the disaster mechanism of the strong ground pressure on the 6107 longwall face of Yuanbao Bay Mine caused by the overlying room pillar collapse. 
The purpose of this simulation is: (1) to simulate the overlying room pillar dynamic collapse process on the 6107 longwall face; (2) to simulate the movement characteristics of the overlying strata after the coal pillar collapse; and (3) to analyze the disaster mechanism based on the collapse process and the characteristics of the overlying strata movement.

We selected a two-dimensional model frame with a dimension of $1.3 \mathrm{~m} \times 0.12 \mathrm{~m} \times 1 \mathrm{~m}$ for the simulation based on the mining conditions and occurrence characteristics of the longwall face. Based on the same conditions, the geometric similarity ratio of the model was 1:100, Poisson's ratio similarity ratio was 1:1, density similarity ratio was 1:1.6, and stress similarity ratio was 1:160. The height of the model was $65 \mathrm{~cm}$. A corresponding load of approximately $80 \mathrm{~m}$ thickness overlying rock was applied to simulate the actual burial depth, equivalently replaced by a uniform load of $12.5 \mathrm{kPa}$ according to the stress similarity ratio. A schematic of the model is shown in Figure 7.

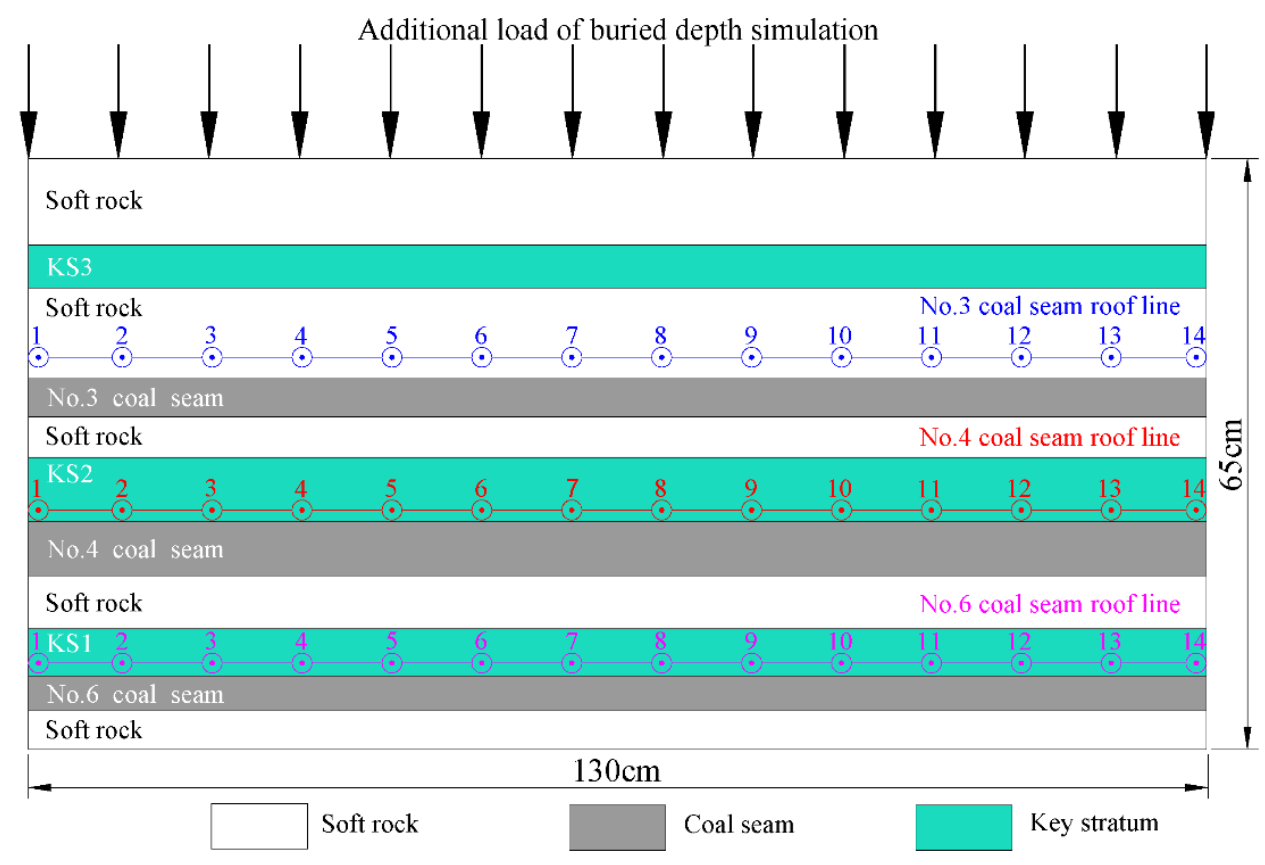

Figure 7. Schematic diagram of similar simulation model.

There are three strata for the overburden according to the borehole columnar section 2101 and the key stratum identification results. The number of key strata was also set to three layers, and the others were replaced by soft rocks whose structure is the interbedded mudstone and sandy mudstone in the bedrock. The mechanical properties of these two rock formations are very similar, so they can be approximately reckoned as the same material to simplify the structure of the overlying rock and reflect the main control effect of the key strata [6]. The thickness of each layer is 1.0-3.5 m; after homogenization, each layer thickness is $2 \mathrm{~cm}$, as shown in Table 1 . 
Table 1. Proportion table of similar materials.

\begin{tabular}{|c|c|c|c|c|c|c|c|c|}
\hline \multirow[b]{2}{*}{ No. } & \multirow[b]{2}{*}{ Lithology } & \multirow[b]{2}{*}{$\mathbf{M}$} & \multicolumn{4}{|c|}{ Material/kg } & \multirow[b]{2}{*}{$\mathbf{t}$} & \multirow[b]{2}{*}{$\mathrm{S}$} \\
\hline & & & Sand & $\begin{array}{c}\text { Calcium } \\
\text { Carbonate }\end{array}$ & Plaster & Water & & \\
\hline 11 & Soft rock & 773 & 21.84 & 2.18 & 0.94 & 2.78 & 10 & 5 \\
\hline 10 & KS3 & 337 & 10.92 & 1.09 & 2.55 & 1.62 & 5 & 1 \\
\hline 9 & Soft rock & 773 & 21.84 & 2.18 & 0.94 & 2.78 & 10 & 5 \\
\hline 8 & No. 3 coal seam & 773 & 8.74 & 0.87 & 0.37 & 1.08 & 4 & 1 \\
\hline 7 & Soft rock & 773 & 8.74 & 0.87 & 0.37 & 1.11 & 4 & 2 \\
\hline 6 & KS2 & 437 & 15.29 & 1.15 & 2.68 & 2.12 & 7 & 1 \\
\hline 5 & No. 4 coal seam & 773 & 13.10 & 1.31 & 0.56 & 1.61 & 6 & 1 \\
\hline 4 & Soft rock & 773 & 13.10 & 1.31 & 0.56 & 1.66 & 6 & 3 \\
\hline 3 & KS1 & 437 & 10.92 & 0.82 & 1.91 & 1.52 & 5 & 1 \\
\hline 2 & No. 6 coal seam & 773 & 8.74 & 0.87 & 0.37 & 1.08 & 4 & 1 \\
\hline 1 & Floor & 673 & 8.74 & 1.02 & 0.44 & 1.13 & 4 & 2 \\
\hline
\end{tabular}

Note: $\mathrm{t}$ is the thickness of strata, $\mathrm{m} ; \mathrm{S}$ is the stratification of strata; $\mathrm{M}$ is the matching number of material.

Observation marks were placed on the roof of each coal seam to understand the subsidence of the coal roof in detail. There were 14 measuring points in each roof line with a $10 \mathrm{~cm}$ interval between them.

The goaf areas of the No. 3 and No. 4 coal seams were designed according to the actual engineering background ratios of mined to unmined width, 1.8 and 2.8, respectively. Generally considered, the widths of the No. 3 coal seam goaf and the coal pillar were 7 and $3 \mathrm{~cm}$, respectively. Meanwhile, the widths of the No. 4 coal seam goaf and the coal pillar were 8 and $2 \mathrm{~cm}$, respectively. Both 6.5 and $6 \mathrm{~m}$ width of coal pillars were left on the model boundaries of the No. 3 and No. 4 coal seams, respectively, to avoid the influence of the model boundary on the goaf during the mining period.

The No. 6 coal seam mining length was $90 \mathrm{~cm}$, with $10 \mathrm{~cm}$ width boundary coal pillars left on both sides. It had a mining step of $5 \mathrm{~cm}$, a total of 18 excavations, and the time interval between each excavation of half an hour was used for the strata to stabilize. Then, we employed high-speed and real-time photography.

\subsection{Dynamic Collapse Process of Room Pillars}

The state of the No. 6 coal seam roof changes significantly, eventually breaks, and the amount of subsidence increases significantly up to $45 \mathrm{~mm}$ when the longwall face advances $70 \mathrm{~cm}$. Then, the advancing distance continues to increase, while the maximum subsidence value of the roof of the No. 6 coal seam no longer increased. However, the lateral range of its movement subsidence increases from 90 to $120 \mathrm{~cm}$, as shown in Figure 8a. Results show that the No. 4 coal seam roof sinks later than the No. 6 coal seam. The No. 4 coal seam roof drastically sinks and breaks after the coal pillar becomes unstable at $70 \mathrm{~cm}$, and the sinking amount suddenly increases to approximately $70 \mathrm{~mm}$. The amount of coal roof subsidence remains unchanged as the longwall face continuously advances, while the subsidence range increased slightly, as shown in Figure 8b. Moreover, the amount of roof subsidence of the No. 3 coal seam increases when the advancing distance is within $60 \mathrm{~cm}$. On the other hand, the advancing distance of the longwall face is $70 \mathrm{~cm}$ when the coal roof breaks and sinks, which is the same position as the roof-breaking movement of the No. 6 and No. 4 coal seams. The amount of subsidence increases up to approximately $90 \mathrm{~cm}$, indicating that the roof of the No. 3 coal seam moves violently after the overburden movement. Moreover, subsequent mining has little effect on the sinking movement of the No. 3 coal seam roof, as shown in Figure 8c. 


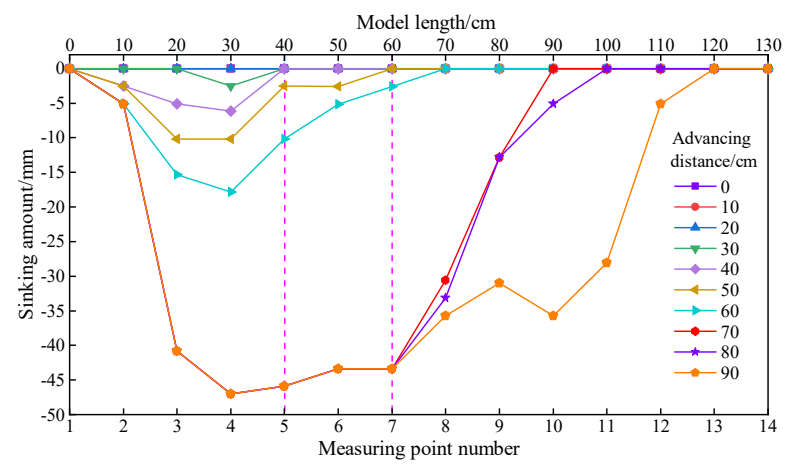

(a)

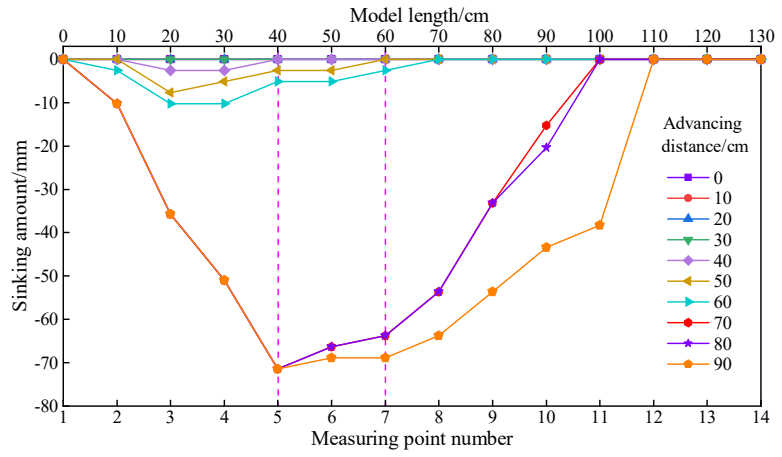

(b)

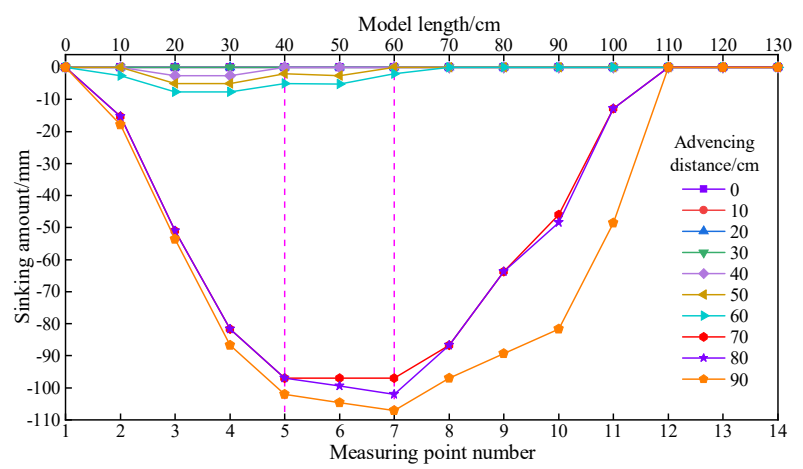

(c)

Figure 8. Coal seam roof subsidence of (a) No. 6, (b) No. 4, and (c) No. 3 during model excavation.

Figure 9 shows the failure sequence and the detailed process of the dynamic collapse of coal pillars of overlying No. 3 and No. 4 coal seams on the longwall face. Additionally, the overlying coal pillars of the No. 3 and No. 4 coal seam rooms and pillar goaf were affected by the mining process of the longwall face, resulting in these two being successively damaged and failing. This caused the large-scale collapse of the two layers of coal pillars, resulting in the occurrence of strong ground pressure on the longwall face.

Both the No. 3 and No. 4 coal seam pillars, which consist of 11 coal pillars from No. 1 to No. 11, are numbered from right to left, as shown in Figure 9a. The first failure occurred at No. 4, No. 5, and No. 11 coal pillars of the No. 4 coal seam. Moreover, the No. 6 coal seam immediate, the controlled strata broke and revolved, and the No. 4 coal seam roof strata bent and sank. Fractures developed directly on the coal seam roof at the position of the setup entry and the No. 6 coal seam longwall face, as shown in Figure 9b. Eventually, the No. 4 and No. 5 coal pillars of the No. 3 coal seam failed, and fractures developed directly on the boundary of the coal pillar of the No. 4 coal seam, as shown in Figure 9c. Additionally, the No. 8 and No. 9 coal pillars of the No. 4 coal seam and No. 3 coal pillar of the No. 3 coal seam successively failed, the immediate roof of the No. 4 coal seam inferior key stratum and its controlled strata broke and rotated, and the No. 3 coal seam overlying strata was bent and subsided, as shown in Figure 9d. Overall, the coal pillars of the No. 4 coal seam above the goaf are all unstable, and the adjacent coal pillars that failed in the No. 3 coal seam have a large number of fractures in the roof, as shown in Figure 9e. The coal pillar of the No. 3 coal seam suffered a large-scale collapse, and the overlying roof strata broke and turned, causing the interburden of No. 3 and No. 4 coal seams to be entirely cut off. Moreover, the immediate roof of the No. 4 coal seam acted on the interburden of the No. 4 and No. 6 coal seams to cut instantaneously and fall down, causing the longwall face support crushing, as shown in Figure $9 \mathrm{f}$. 


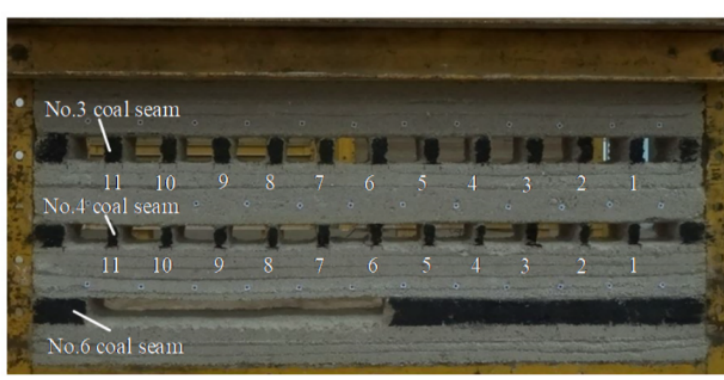

(a)

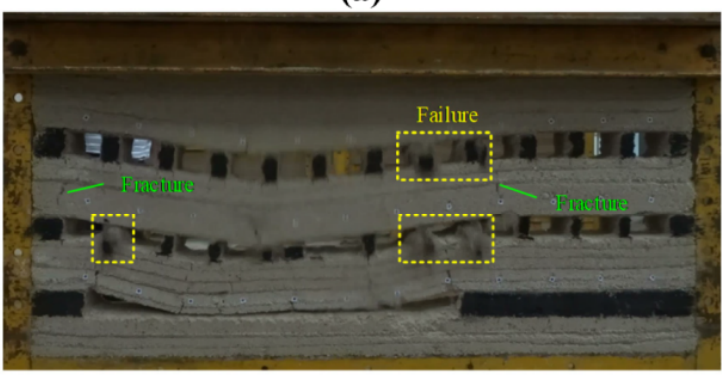

(c)

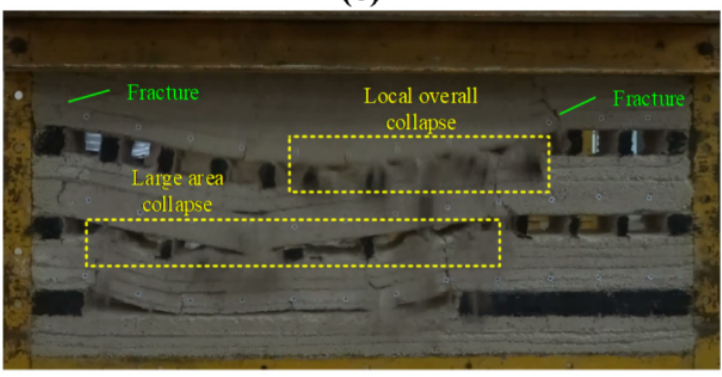

(e)

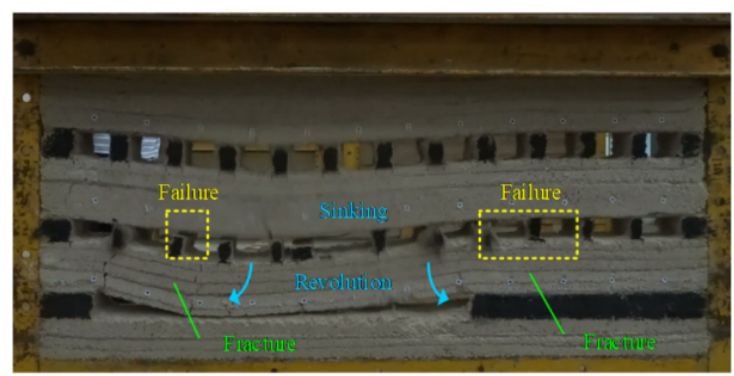

(b)

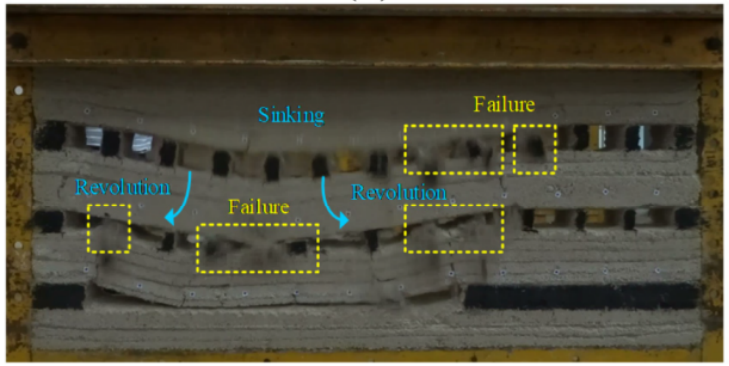

(d)

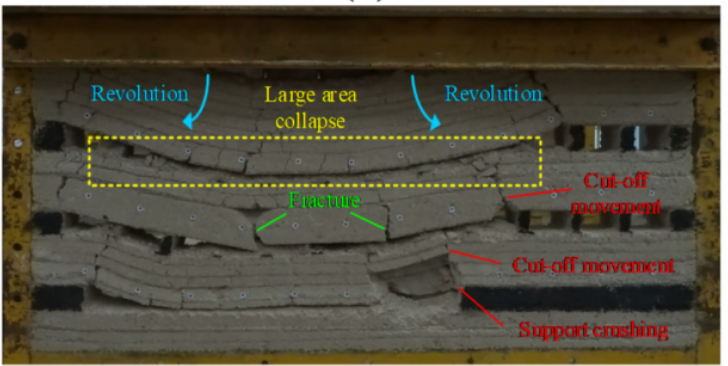

(f)

Figure 9. Dynamic collapse process of room-and-pillar mining pillars. (a) Before the coal pillar loses stability; (b) No. 4, No. 5, and No. 11 coal pillars fail first; (c) No. 4 and No. 5 coal pillars fail successively; (d) No. 8 and No. 9 coal pillars fail; (e) Large area of coal pillar collapse; (f) Support crushing under strong ground pressure at longwall face.

\subsection{Analysis of the Disaster Mechanism of the Strong Ground Pressure}

We obtained a model of the dynamic collapse of the coal pillar disaster mechanism based on the aforementioned process, as shown in Figure 10.

The immediate roof of the longwall face is a hard, inferior key stratum. The longwall face is affected by the advancing abutment pressure [45-47] when it advances to form a larger span. The diagonal failure of the coal pillars of the No. 4 coal seam above the setup entry and longwall face occurs first because the peak value of the advancing abutment pressure is larger than the compressive strength of the coal pillar, as shown in Figure 10a. The stress from the diagonal failure was instantly transferred to the pillars above the goaf, resulting in the breakage and rotation of the immediate roof that was exposed in the goaf of the longwall face of the No. 6 coal seam due to the sudden increase in stress. Additionally, the space of the immediate roof rotation was limited by the mining height, which forced the rotation to stop. Specifically, the No. 4 coal seam pillars overlying the mined-out area were subjected to excessive overburden load and collapsed. After this large-scale failure, the immediate roof also stopped moving in the limited space. On the other hand, the No. 3 coal seam pillars overlying the setup entry and longwall face were also diagonally damaged during the movement of the strata below, as shown in Figure 10b. Moreover, the advancing abutment pressure was continuously being transferred to the undamaged coal pillars of the No. 3 coal seam, resulting in the advanced coal pillar failure. The load of the No. 3 coal seam was concentrated on the coal pillars that had not failed in the middle. The coal pillars were destroyed and failed in a larger area due to the significant pressure from the overload. 
The inferior key stratum of each coal seam and the controlled strata developed through fractures. The No. 3 coal seam roof strata also tended to move instantaneously because of the loss of the coal pillar support, as shown in Figure 10c. Moreover, the overlying strata of the No. 3 coal seam were entirely cut off along the through fractures of the overlying strata after the pillars of the No. 3 coal seam suffered a large area of collapse because there was no coal pillar support. This directly impacted the underlying strata of the No. 3 coal seam, and eventually, the interburden of the No. 3 and No. 4 coal seams were entirely cut off along its through fractures. The two huge impacts formed by the overall cutting of the two parts of the No. 4 coal seam overlying strata were superimposed on each other, acting on the interburden of the No. 4 and No. 6 coal seams. The violent impact made it instantly cut down along the entire intersecting fractures, directly acting on the longwall face that caused a strong ground pressure and caused the longwall face support crushing, as shown in Figure 10d.

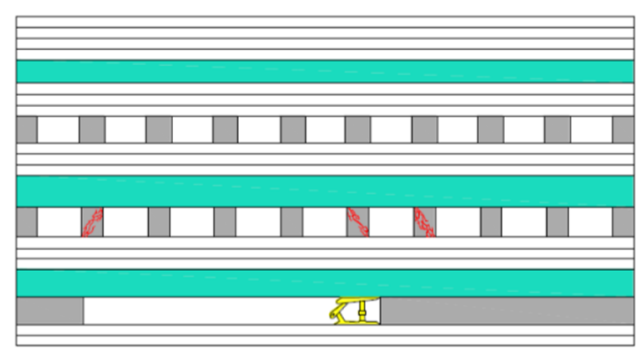

(a)

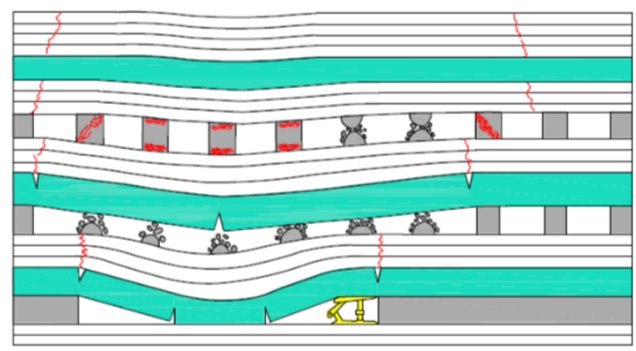

(c)

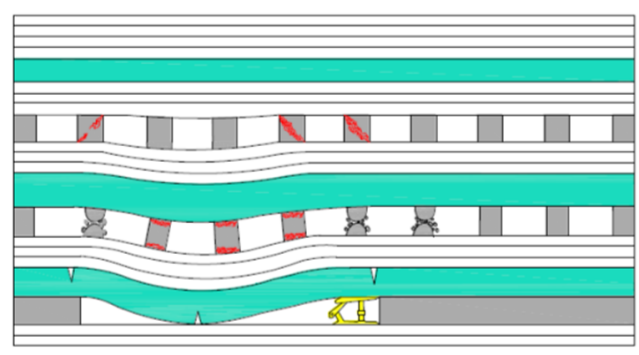

(b)

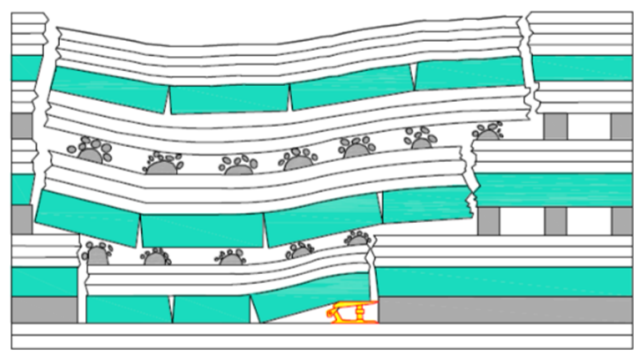

(d)

Figure 10. Diagram of disaster mechanism caused by dynamic collapse of coal pillars. (a) Diagonal failure of pillars of the No. 4 coal seam first occurs; (b) Continuous shear failure of adjacent coal pillars; (c) Local overall failure of pillars of No. 3 coal seam; (d) Whole-rock strata cut to strong ground.

\section{Conclusions}

In this study, the collapse and fracture of the coal pillar group and the movement characteristics of the overlying strata in the undermining process employed at the Yuanbao Bay 6107 longwall face are determined and investigated. The principles caused by the dynamic collapse of the coal pillar and the disaster mechanism of the strong ground pressure are identified and investigated using strata movement monitoring, borehole peeping, similar simulation experiments, and simplified model deepening analysis. The main conclusions of this study are as follows:

(1) Results show that the overlying strata movement presents the movement characteristics of the entire step subsidence, while the staggered hole position of each borehole shows the characteristics of the stage step rise. Particularly, the strata movement data of each measuring point in boreholes No. 6 and No. 10 significantly increased when the strong ground pressure occurred. Simultaneously, the staggered position of each borehole moves upward, which is consistent with the time and position of the occurrence of the strong ground pressure on the 6107 longwall face. Moreover, the 
collapse of the coal pillar left by the No. 4 coal seam leads to a strong ground pressure phenomenon on the 6107 longwall face.

(2) Without undermining, the No. 3 and No. 4 coal pillars, which are affected by their sizes, can maintain long-term stability. Meanwhile, in undermining conditions, the No. 4 coal pillars were found to be unable to maintain stability caused by the initial coal pillar collapse due to the influence of the advancing abutment pressure, while the No. 3 coal pillars can maintain stability.

(3) The overlying coal pillars of the No. 4 coal seam were first diagonally damaged at both ends above the goaf, and then the coal pillar above the middle of the goaf was instantaneously invalidated because of the effect of mining of the longwall face. Moreover, the coal pillars of the No. 4 coal seam had a wide range of overall collapse. On the other hand, the coal pillars of the No. 3 coal seam at the corresponding position of the goaf were diagonally damaged. Additionally, the pillars of the No. 3 coal seam were destabilized on a large scale, wherein failure on both sides and in the middle was apparent. Eventually, both pillars of the No. 3 and No. 4 coal seam experienced large-scale collapse.

(4) The causes of the strong ground pressure on the longwall face are the overall large cutting movement of the overburden and the large area collapse of the coal pillar, which is influenced by the advancing abutment pressure. After the large-scale collapse of the coal pillar, the overlying strata has a large subsidence movement without the support of the coal pillar. This may cause the strata to be cut down entirely, directly or indirectly impacting the longwall face, which causes a strong ground pressure on the longwall face and support crushing.

Author Contributions: For this paper, W.Z. put forward study ideas; D.Y. designed the article structure and wrote the paper; Z.L. revised the whole English writing style and discussed the design flow with W.Z.; X.Y. collected and analyzed the data from mine site; J.L. conducted the similar simulation experiment and analyzed the data. All authors have read and agreed to the published version of the manuscript.

Funding: This research was funded by the National Natural Science Foundation of China (Grant No. 52074265, No. 51874175).

Acknowledgments: The authors would like to thank the reviewers for their constructive comments, which improved the paper and anonymous colleagues for their kind efforts and valuable comments, which have improved this work.

Conflicts of Interest: The authors declare no conflict of interest.

\section{References}

1. Zhu, W.B. Study on the Instability Mechanism of Key Strata Structure in Repeating Mining of Shallow Close Distance Seams. Ph.D. Thesis, China University of Mining and Technology, Xuzhou, China, 2010.

2. Mark, C.; Tuchman, R.J. Multiple-Seam Longwall Mining in the United States: Lessons for Ground Control. New Technology for Ground Control in Multiple-Seam Mining; Department of Health and Human Services, Public Health Service, Centers for Disease Control and Prevention, National Institute for Occupational Safety and Health: Pittsburgh, PA, USA, 2007; pp. 45-53.

3. Suchowerska, A.M. Geomechanics of Single Seam and Multi Seam Longwall Coal Mining. Ph.D. Thesis, University of Newcastle, Callaghan, Australia, 2014.

4. Porathur, J.L.; Srikrishnan, S.; Verma, C.P.; Jhanwar, J.C. Slope stability assessment approach for multiple seams highwall mining extractions. Int. J. Rock Mech. Min. Sci. 2014, 70, 444-449. [CrossRef]

5. Ghabraie, B.; Ren, G.; Barbato, J.; Smith, J. A predictive methodology for multi-seam mining induced subsidence. Int. J. Rock Mech. Min. Sci. 2017, 93, 280-294. [CrossRef]

6. Qian, M.G.; Shi, P.W.; Xu, J.L. Ground Pressure and Strata Control; China University of Mining and Technology Press: Xuzhou, China, 2010.

7. Chen, D.D.; He, F.L.; Xie, S.R.; Gao, M.M.; Song, H.Z. First fracture of the thin plate of main roof with three sides elastic foundation boundary and one side coal pillar. J. Coal Sci. Eng. (China) 2017, 42, 2528-2536.

8. Djamaluddin, I.; Mitani, Y.; Ikemi, H. GIS-Based Computational Method for Simulating the Components of 3D Dynamic Ground Subsidence during the Process of Undermining. Int. J. Geomech. 2012, 12, 43-53. [CrossRef]

9. Adelsohn, E.; Iannacchione, A.; Winn, R. Investigations on longwall mining subsidence impacts on Pennsylvania highway alignments. Int. J. Min. Sci. Technol. 2020, 30, 85-92. [CrossRef] 
10. Sidorenko, A.A.; Sirenko, Y.G.; Sidorenko, S.A. An assessment of multiple seam stress conditions using a 3-D numerical modelling approach. J. Phys. Conf. Ser. IOP Publ. 2019, 1333, 032078. [CrossRef]

11. Kellich, W.; Lee, J.W.; Aziz, N.; Baafi, E. Numerical Modelling of Undermined River Valleys-A Case Study. In Proceedings of the 2005 Coal Operators' Conference, Wollongong, Australia, 26-28 April 2005; Aziz, N., Kininmonth, B., Eds.;

12. Coulthard, M.A. Undermining of an unlined tunnel in rock. In FLAC and Numerical Modeling in Geomechanics; CRC Press: Boca Raton, FL, USA, 2020; pp. 265-272.

13. Reed, G.; Kent, M.; Russell, F. An assessment of coal pillar system stability criteria based on a mechanistic evaluation of the interaction between coal pillars and the overburden. Int. J. Min. Sci. Technol. 2017, 27, 9-15. [CrossRef]

14. Poulsen, B.A.; Adhikary, D.P. A numerical study of the scale effect in coal strength. Int. J. Rock Mech. Min. Sci. 2013, 63, 62-71. [CrossRef]

15. Poulsen, B.A. Coal pillar load calculation by pressure arch theory and near field extraction ratio. Int. J. Rock Mech. Min. Sci. 2010, 47, 1158-1165. [CrossRef]

16. Singh, R.; Kumar, A.; Singh, A.K.; Coggan, J.; Ram, S. Rib/snook design in mechanised depillaring of rectangular/square pillars. Int. J. Rock Mech. Min. Sci. 2016, 84, 119-129. [CrossRef]

17. Atsushi, S.; Mitri, H.S. Numerical investigation into pillar failure induced by time-dependent skin degradation. Int. J. Min. Sci. Technol. 2017, 27, 591-597.

18. Maleki, H. Coal pillar mechanics of violent failure in U.S. Mines. Int. J. Min. Sci. Technol. 2017, 27, 387-392. [CrossRef]

19. Poulsen, B.A.; Shen, B. Subsidence risk assessment of decommissioned bord-and-pillar collieries. Int. J. Rock Mech. Min. Sci. 2013, 60, 312-320. [CrossRef]

20. Sinha, S.; Walton, G. Modeling behaviors of a coal pillar rib using the progressive S-shaped yield criterion. J. Rock Mech. Geotech. Eng. 2020, 12, 484-492. [CrossRef]

21. Kushwaha, A.; Singh, S.K.; Tewari, S.; Sinha, A. Empirical approach for designing of support system in mechanized coal pillar mining. Int. J. Rock Mech. Min. Sci. 2010, 47, 1063-1078. [CrossRef]

22. Xu, J.M.; Zhu, W.B.; Xu, J.L.; Wu, J.Y.; Li, Y.C. High-intensity longwall mining-induced ground subsidence in Shendong coalfield, China. Int. J. Rock Mech. Min. Sci. 2021, 141, 104730. [CrossRef]

23. Ju, J.F.; Xu, J.L. Prevention measures for support crushing while mining out the upper coal pillar in close distance shallow seams. J. Min. Saf. Eng. 2013, 30, 323-330.

24. Zhu, C.; He, M.C.; Zhang, X.H.; Tao, Z.G.; Yin, Q.; Li, L.F. Nonlinear mechanical model of constant resistance and large deformation bolt and influence parameters analysis of constant resistance behavior. Rock Soil Mech. 2017, 42, 1911-1924.

25. Wang, X.Z.; Zhu, W.B.; Xu, J.L.; Han, H.K.; Fu, X. Mechanism of overlying strata structure instability during mining below unconsolidated confined aquifer and disaster prevention. Appl. Sci. 2021, 11, 1778. [CrossRef]

26. Yu, S.C.; Xu, J.M.; Zhu, W.B.; Wang, S.H.; Liu, W.B. Development of a combined mining technique to protect the underground workspace above confined aquifer from water inrush disaster. Bull. Eng. Geol. Environ. 2020, 79, 3649-3666. [CrossRef]

27. Huang, Q.X.; Zhao, M.Y.; Huang, K.J. Study of roof double key strata structure and support resistance of shallow coal seams group mining. Int. J. Min. Sci. Technol. 2019, 48, 71-86.

28. Zhu, W.B.; Chen, L.; Zhou, Z.L.; Shen, B.T.; Xu, Y. Failure propagation of pillars and roof in a room and pillar mine induced by longwall mining in the lower seam. Rock Mech. Rock Eng. 2019, 52, 1193-1209. [CrossRef]

29. Feng, G.; Kang, Y.; Wang, X.C.; Hu, Y.Q.; Li, X.H. Investigation on the failure characteristics and fracture classification of shale under brazilian test conditions. Rock Mech. Rock Eng. 2020, 53, 3325-3340. [CrossRef]

30. Wang, Q.; He, M.C.; Li, S.C.; Jiang, Z.H.; Wang, Y.; Qin, Q.; Jiang, B. Comparative study of model tests on automatically formed roadway and gob-side entry driving in deep coal mines. Int. J. Min. Sci. Technol. 2021, 31, 591-601. [CrossRef]

31. Wang, Q.; Wang, Y.; He, M.C.; Jiang, B.; Li, S.C.; Jiang, Z.H.; Wang, Y.J.; Xu, S. Experimental research and application of automatically formed roadway without advance tunneling. Tunn. Undergr. Space Technol. 2021, 114, 103999. [CrossRef]

32. Feng, G.R.; Zhang, X.Y.; Li, J.J.; Yang, S.S.; Kang, L.X. Feasibility on the upward mining of the left-over coal above goaf with pillar supporting method. J. China Coal Soc. 2009, 34, 726-730.

33. Newman, C.; Newman, D. Numerical analysis for the prediction of bump prone conditions: A southern Appalachian pillar coal bump case study. Int. J. Min. Sci. Technol. 2021, 31, 75-81. [CrossRef]

34. Kozyreva, E.N.; Shinkevich, M.V. Evaluation of safe (by gas criterion) process parameters for longwalls and gateways based on operational gas content measurement in coal seams. In IOP Conference Series: Earth and Environmental Science; IOP Publishing: Bristol, UK, 2019; Volume 377, p. 012054.

35. Meshkov, A.; Kazanin, O.; Sidorenko, A. Methane Emission Control at the High-Productive Longwall Panels of the Yalevsky Coal Mine. In E3S Web Conferences; EDP Sciences: Evry, France, 2020; Volume 174, p. 01040.

36. Wang, M.L.; Zhang, H.X.; Zhang, G.Y. Safety assessment of ascending longwall mining over old rib pillar gobs. J. Min. Saf. Eng. 2008, 25, 87-90.

37. Dychkovskyi, R.; Shavarskyi, I.; Saik, P.; Lozynskyi, V.; Falshtynskyi, V.; Cabana, E. Research into stress-strain state of the rock mass condition in the process of the operation of double-unit longwalls. Min. Miner. Depos. 2020, 14, 85-94. [CrossRef]

38. Du, W.G.; Chai, J.; Zhang, D.D.; Lei, W.L. The study of water-resistant key strata stability detected by optic fiber sensing in shallow-buried coal seam. Int. J. Rock Mech. Min. Sci. 2021, 141, 104604. [CrossRef] 
39. Ren, Y.W.; Yuan, Q.; Chai, J.; Liu, Y.L.; Zhang, D.D.; Liu, X.W.; Liu, Y.X. Study on the clay weakening characteristics in deep unconsolidated layer using the multi-point monitoring system of FBG sensor arrays. Opt. Fiber Technol. 2021, 61, 102432. [CrossRef]

40. Zhang, D.D.; Du, W.G.; Chai, J.; Lei, W.L. Strain Test Performance of Brillouin Optical Time Domain Analysis and Fiber Bragg Grating Based on Calibration Test. Sens. Mater. 2021, 33, 1387-1404.

41. Peng, S.S.; Chiang, H.S. Longwall Mining; Wiley: New York, NY, USA, 1984; p. 708.

42. Małkowski, P.; Niedbalski, Z.; Majcherczyk, T.; Bednarek, Ł. Underground monitoring as the best way of roadways support design validation in a long time period. Min. Miner. Depos. 2020, 14, 1-14. [CrossRef]

43. Yin, Q.; Wu, J.Y.; Zhu, C.; He, M.C.; Meng, Q.X. Shear mechanical responses of sandstone exposed to high temperature under constant normal stiffness boundary conditions. Geomech. Geophys. Geo-Energy Geo-Resour. 2021, 7, 35. [CrossRef]

44. Lou, J.F.; Gao, F.Q.; Yang, J.H.; Ren, Y.F.; Li, J.Z.; Wang, X.Q.; Yang, L. Characteristics of evolution of mining-induced stress field in the longwall panel: Insights from physical modeling. Int. J. Coal Sci. Technol. 2021, 27, 1-18.

45. Ren, Y.F.; Ning, Y. Changing feature of advancing abutment pressure in shallow long wall working face. J. China Coal Soc. 2014, $39,38-42$.

46. Jin, Z.Y.; Ma, L.Q.; Sun, Q. Impact factors of the distribution of advancing abutment pressure at comprehensive mechanized mining face. Electron. J. Geotech. Eng. 2015, 20, 1740-1741.

47. Cheng, Z.H.; Qin, H.Y.; Chen, L.; Zhao, X.D.; Yin, S.F. Relationship between mining thickness and peak position of advancing abutment pressure: A case study in Helin coal mine in China. Arab. J. Geosci. 2021, 14, 1-8. [CrossRef] 